339.972

JEL Q57

DOI 10.31375/2226-1915-2020-3-22-42

Tetiana Kovtun

Ph.D., Associate Professor, Associate Professor of the Department «Logistic Systems and Projects Management»

ORCID: https://orcid.org/0000-0002-5410-4783

teta.kovtun@gmail.com

Odessa National Maritime University, Odessa, Ukraine

\title{
IMPLEMENTATION OF THE CIRCULAR ECONOMY PRINCIPLES TO ACHIEVE SUSTAINABLE DEVELOPMENT GOALS
}

\begin{abstract}
The concept of a circular economy, which is a practical basis for the implementation of an environmental economy and offers effective business models to ensure more efficient use of resources, contributing to the achievement of sustainable development goals, is studied in the article.

The main processes of the eco-destructive influence of mankind on the environment are characterized. To determine the degree of eco-destructive influence allows a special indicatorthe ecological footprint showing the demand of the human population for natural capital.

It is possible to reduce the effects of eco-destructive impact on nature through the introduction of new life concepts. The connection between the concepts of sustainable development, environmental economics and circular economy is traced. An environmental economy is one way to achieve sustainable development, and a circular economy is a specific tool for the transition to an environmental economy.

Circular economy is one of the directions of the green economy. The systems approach presents a circular economy as a model of an economic system, which is an element of a technogenic systemand is based on the reuse of materials, thereby conserving natural resources, and considers the issue of creating value for the elements of the system.

It is shown that the principles of the circular economy are implemented through five business models, the introduction of which is possible due to the combination of the circular economy processes in frameworks of varying complexity from « $4 R$ » to « $9 R$ » based on industrial metabolism and symbiosis, when the interaction between the elements of the technogenic system can be carried out at the micro-, meso- and macrolevels in resourced according to the cascade principle, when the wastes of one production are raw materials for another, thereby ensuring a decrease in the eco-destructive impact on the environment.

The circular economy takes into account the biological and technical cycles of the circulation of resources and the potential benefits that can be obtained at different levels of these cycles, it involves a transition from a linear economy to a closed-loop economy.

The introduction of a circular economy requires changes in existing logistics systems. Closed supply chains are created that combine the usual processes of a direct supply chain with reverse logistics processes, which can significantly reduce the eco-destructive impact on the environment.

Keywords: sustainable development, eco-destructive influence, circular economy, closed supply chain.
\end{abstract}

\section{(C) Ковтун T.А., 2020}


DEVELOPMENT OF MANAGEMENT AND ENTREPRENEURSHIP METHODS ON TRANSPORT, № 3 (72), 2020
РОЗВИТОК МЕТОДІВ

УПРАВЛІННЯ ТА ГОСПОДАРЮВАННЯ

НА ТРАНСПОРТІ, № 3 (72), 2020
УДК 339.972

JEL Q57

DOI 10.31375/2226-1915-2020-3-22-42

T.А. Ковтун

к.т.н., доцент, доцент кафедри «Управління логістичними системами та проектами» ORCID: https://orcid.org/0000-0002-5410-4783 teta.kovtun@gmail.com Одеський начіональний морський університет, Одеса, Украӥна

\section{ВПРОВАДЖЕННЯ ПРИНЦИПІВ ЦИРКУЛЯРНОЇ ЕКОНОМІКИ ДЛЯ ДОСЯГНЕННЯ ЦІЛЕЙ СТАЛОГО РОЗВИТКУ}

Анотація. У статті досліджена концепція ииркулярної економіки, яка виступае практичною основою реалізачії екологічної економіки і пропонує дієві бізнес-моделі для забезпечення більи ощзадливого ресурсокористування, сприяючи досягненню цілей сталого розвитку.

Надано характеристику основних проиесів екодеструктривного впливу людства на довкілля. Визначити ступінь екодеструктивного впливу дозволяс спеціальний показник екологічний слід, щчо відображає попит людської популяції на природний капітал.

Зменшити наслідки екодеструктивного впливу на природу можливо завдяки впровадженню нових кониепиій жситтєдіяльності. Простежений зв'язок між концепиіями сталого розвитку, екологічної економіки та ијиркулярної економіки. Екологічна економіка $\epsilon$ одним зі способів досягнення сталого розвитку, а ииркулярна економіка є конкретним інструментом переходу до екологічної економіки.

Циркулярна економіка є одним з напрямків еколого-орієнтованої економіки. Системний підхід представляє ииркулярну економіку як модель економічної системи, яка $\epsilon$ елементом техногенної системи та базується на повторному використанні матеріалів, завдяки чому зберігатимуться природні ресурси, та розглядає питання створення цуінності для елементів системи.

Показано, щзо реалізаиія принциипів и̧иркулярної економіки здійснюється через n'ять бізнес-моделей, впровадити які можливо завдяки комбінації прочесів ииркулярної економіки в фреймворки різного ступеню складнос- mi від «4R» до «9R» на основі індустріального метаболізму та симбіозу, коли взаємодія між елементами техногенної системи може здійснюватися на мікро-, мезо- та макрорівні в ресурсному забезпеченні за каскадним приниипом, коли відходи одного виробниитва $\epsilon$ сировиною для іншого, забезпечуючи тим самим зменшення екодеструктивного впливу на довкілля.

Циркулярна економіка враховує біологічний та технічний иикли обігу ресурсів та потениійні вигоди, які можуть бути отримані на різних рівнях иих ииклів, вона передбачає перехід від лінійної економіки до економіки замкнутого циклу.

Впровадження циркулярної економіки потребує змін в існуючих логістичних системах. Створюються замкнуті ланцюги поставок, які об'єднують звичайні прочзеси прямого ланцюга поставок зі зворотними логістичними прочесами, щзо дозволяе значно зменшити екодеструктивний вплив на довкілля.

Ключові слова: сталий розвиток, екодеструктивний вплив, ичиркулярна економіка, замкнутий ланцюг поставок

\section{УДК 339.972}

JEL Q57

DOI 10.31375/2226-1915-2020-3-22-42

Т.А. Ковтун

к.т.н., доцент, доцент кафедры «Управление логистическими системами и проектами»

ORCID: https://orcid.org/0000-0002-5410-4783 teta.kovtun@gmail.com Одесский национальный морской университет, Одесса, Украина

\section{ВНЕДРЕНИЕ ПРИНЦИПОВ ЦИРКУЛЯРНОЙ ЭКОНОМИКИ ДЛЯ ДОСТИЖЕНИЯ ЦЕЛЕЙ УСТОЙЧИВОГО РАЗВИТИЯ}

Аннотация. В статье исследована концепция циркулярной экономики, которая является практической основой реализачии экологической экономики и предлагает действенные бизнес-модели для обеспечения более бережливого использования ресурсов, способствуя достижению целей устойчивого развития. Охарактеризованы основные прочессы экодеструктивного влияния человечества на окружающую среду. Определить степень эко- 
деструктивного влияния позволяет специальный показатель - экологический след, отражаюший спрос человеческой популящии на природный капитал. Уменьшить последствия экодеструктивного влияния на природу возможно благодаря внедрению новых кониепциий жизнедеятельности. Прослежена связь между концепциями устойчивого равития, экологической экономики и цуиркулярной экономики. Экологическая экономика является одним из способов достижения устойчивого развития, а циикклярная экономика является конкретным инструментом перехода к экологической экономике. Циркулярная экономика является одним из направлений эколого-ориентированной экономики. Системный подход представляет ицикулярную экономику как модель экономической системы, которая является элементом техногенной системы и базируется на повторном использовании материалов, благодаря чему сохраняются природные ресурсы, и рассматривает вопрос создания ценности для элементов системы.

Показано, что реализация принцииов циикулярной экономики осуществляется посредством пяти бизнес-моделей, внедрение которых возможно благодаря комбинации процессов циркулярной экономики в фреймворки разной степени сложности от «4R»до «9R» на основе индустриального метаболизма и симбиоза, когда взаимодействие между элементами техногенной системь может осуществляться на микро-, мезо- и макроуровне в ресурсном обеспечении по каскадному принципу, когда отходы одного производства являются сырьем для другого, обеспечивая тем самым уменьшение экодеструктивного влияния на окружающую среду.

Циркулярная экономика учитывает биологический и технический цикль обращения ресурсов и потенциальные выгоды, которые могут быть получены на разных уровнях этих цииклов, она предполагает переход от линейной экономики к экономике замкнутого цчикла.

Внедрение ичиркулярной экономики требует изменений в сущуествующих логистических системах. Создаются замкнутые иепи поставок, которые объединяют обычные процессы прямой цепи поставок с обратными логистическими процессами, что позволяет значительно уменьшить экодеструктивное влияние на окружаюшую среду.
Ключевые слова: устойчивое развитие, экодеструктивное влияние, цииркулярная экономика, замкнутая цеепь поставок.

Постановка проблеми. На сучасному етапі еволюції людства досягнення сталого розвитку стало важливим завданням глобального порядку денного. Створений за останні століття техногенний тип економіки призвів до екологічної кризи, оскільки виявився нездатним забезпечити збалансований цивілізаційний розвиток людства без шкоди для довкілля. Глобальна екологічна криза проявляється як напружений стан взаємовідносин між людством і природою, що характеризується невідповідністю існуючої лінійної економічної моделі ресурсним можливостям біосфери.

Сьогодні біосфера не в змозі боротися 3 наслідками людської діяльності, в ній почалися незворотні зміни. Людство виробляе відходів органічного походження в 2000 разів більше, ніж вся природа [1]. Для зниження навантаження на навколишнє середовище потрібна зміна існуючого типу організації економіки на іншу, більш гуманну парадигму.

Починаючи 3 другої половини XX століття, відбувається інтенсивний пошук нової стратегії виживання людства в умовах обмеженості природних ресурсів і погіршення умов існування. На даний час виходом 3 ситуації, що склалася, визнано застосування концепції сталого розвитку, яка передбачає гармонійне співіснування суспільства та суспільства, що потребує врахування екологічних аспектів у всіх сферах життєдіяльності людини.

Гармонійного узгодження компонентів сталого розвитку, що забез- 
DEVELOPMENT OF MANAGEMENT AND ENTREPRENEURSHIP METHODS ON TRANSPORT, № 3 (72), 2020
РОЗВИТОК МЕТОДІВ

УПРАВЛІННЯ ТА ГОСПОДАРЮВАННЯ

НА ТРАНСПОРТІ, № 3 (72), 2020 печує економічне зростання, соціальну стабільність та екологічну рівновагу в довгостроковій перспективі можливо досягти завдяки впровадженню принципів екологічної (зеленої) економіки, якій останнім часом приділяється підвищена увага фахівців в усьому світі.

Екологічна економіка має ряд принципів, серед яких виділяють: принцип забезпечення сталого розвитку; принцип екологічно безпечного бізнесу; принцип необхідності затвердження екологічного стилю життя; принцип циркулярності тощо. Розвиток екологічної економіки призвів до виокремлення напрямків, що відповідають принципам екологізації економіки та зосереджуються на досягненні певних цілей сталого розвитку, а саме: циркулярна економіка, біоекономіка, низьковуглецева економіка, спільна економіка, синя економіка тощо. Кількість напрямків екологічної економіки може збільшуватись в процесі еволюції світогляду людства та визначення нових шляхів досягнення цілей сталого розвитку.

Перехід до циркулярної економіки набуває глобального характеру, i переваги впровадження даної концепції стають все більш очевидними. За оцінками експертів Фонду Еллен МакАртур (Ellen MacArthur Foundation) в 2025 році циркулярна економіка може щорічно забезпечувати приріст доходу світової економіки понад 1 трлн. доларів США. Крім цього, перехід до циркулярної економіки створить величезні можливості для модернізації виробництва i впровадження промислових інновацій, забезпечуючи щорічний приріст ВВП на $7 \%$ [2].
Огляд останніх досліджень та публікацій. Концепція сталого розвитку була прийнята в 1992 році в Ріо-де-Жанейро на Конференції ООН 3 навколишнього середовища та розвитку, в якій прийняли участь уряди та експерти 179 країн, а також представники багатьох неурядових організацій, наукових та ділових кіл [3]. На конференції було прийнято ряд важливих документів, що визначають стратегію розвитку людства на засадах сталого розвитку, в тому числі «Порядок денний на XXI століття» («Agenda 21») [4], орієнтований на підготовку світової спільноти до рішення еколого-економічних і соціально-економічних проблем близького майбутнього [3], в якому сформульовано поняття сталого розвитку як такого, що задовольняє потреби теперішнього часу, але не ставить під загрозу здатність майбутніх поколінь задовольняти свої власні потреби [5].

Програма ООН 3 навколишнього середовища (United Nations Environment Programme, ЮНЕП) в 2011 році випустила доповідь «Назустріч зеленій економіці: шляху до сталого розвитку і викорінення бідності» («Towards a Green Economy: Towards Sustainable Development and Poverty Eradication»), згідно 3 якою зеленою (екологічною) $є$ така економіка, яка забезпечує довгострокове підвищення добробуту людей, дозволяючи майбутнім поколінням уникнути істотних ризиків для навколишнього середовища [6], тобто задовольняє умовам сталого розвитку.

Вперше розвиток сфери ефективного поточного та вторинного використання продукції та рециклінгу визначено як перспективний напрямок розвитку економіки в Доповіді 
DEVELOPMENT OF MANAGEMENT AND ENTREPRENEURSHIP METHODS ON TRANSPORT, № 3 (72), 2020
РОЗВИТОК МЕТОДІВ

УПРАВЛІННЯ ТА ГОСПОДАРЮВАННЯ

НА ТРАНСПОРТІ, № 3 (72), 2020
Римського клубу («Club of Rome») «Межі зростання» («The Limits to growth») [7], яка опублікована в 1975 році та містить результати аналізу можливого розвитку цивілізації з урахуванням потенційного росту популяції, масштабів використання природних ресурсів, екологічних проблем.

У 2015 році Європейська комісія звернулась до Європарламенту i Ради Європи, соціально-економічного і регіонального комітетів 3 доповіддю «Замикання циклу - План дій $\mathrm{CC}$ щодо циркулярної економіки» («Closing the loop - An EU action plan for the Circular Economy») [8], в якій обгрунтувала концепцію циркулярної економіки.

Методологічні підходи, що становлять основу циркулярної економіки, не $\epsilon$ принципово новими. Міждисциплінарна за своїм змістом сучасна концепція циркулярної економіки $€$ результатом наукових досліджень вчених в області екологічної (зеленої) економіки [9; 10], промислової (індустріальної) екології [11-13], економіки природокористування [14; 15] тощо.

Вивченню питань циркулярної економіки присвячені роботи таких авторів, як: Y. Kalmykova, L. Rosado [16], P. Ghisellini, C. Cialani, S. Ulgiati [17], G. Roos [18], A. Murray, K. Skene, K. Haynes [19], W. Haas, F. Krausmann, D. Wiedenhofer, M. Heinz [20], C.B. Мішенін, I.I. Коблянська [21], Н.В. Пахомова, К.К. Рихтер, М.А. Ветрова [22], Н. Батова, П. Сачек, І. Точицька [23; 24], Валько [25; 26] та ін.

До визначення сутності циркулярної економіки існує два підходи: ресурсо-орієнтований (потоковий) та економіко-орієнтований (системний).
Відповідно до потокового підходу [27-30], циркулярна економіка базується на застосуванні замкнутих потоків матеріалів, енергії та відходів, яких можна досягти завдяки повторному використанню продукту (ремонт або відновлювання), компонентів (повторне використання в виробництві), сировини та матеріалів (рециркуляція).

Системний підхід [31-33] представляє циркулярну економіку як модель економічної системи, яка $є$ елементом техногенної системи та базується на повторному використанні ма-теріалів, завдяки чому зберігатимуться природні ресурси, та розглядає питання створення цінності для елементів системи.

Найбільш вживаним та таким, що враховує вищенаведені підходи до визначення сутності циркулярної економіки, $\epsilon$ трактування циркулярної економіки, надане експертами Фонду Еллен МакАртур [2; 34], відповідно якому циркулярна економіка - це економіка, що має відновлювальний та замкнутий характер, передбачає створення безперервного циклу розвитку, який зберігає природний капітал та збільшує його вартість, підвищуючи віддачу від ресурсів за рахунок оптимізації їх використання.

Питанням дослідження сутності циркулярної економіки, iï процесів та бізнес-моделей на даний час приді-

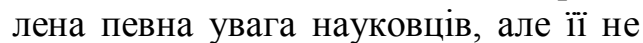
можна вважати достатньою, оскільки дана концепція $\epsilon$ не просто новим напрямком розвитку наукової думки в межах економічної науки, а, як складова екологічної економіки, являє собою міждисциплінарний підхід, основним завданням якого $є$ створення теоретичного підгрунтя для 
зміни світогляду людства на більш гуманний по відношенню до довкілля.

Мета та завдання дослідження. Метою наукової статті $є$ розгляд теоретичної моделі циркулярної економіки, визначення іiі особливостей та напрямків подальшого розвитку. Для досягнення мети дослідження поставлені наступні завдання:

1. Визначити роль циркулярної економіки в досягненні цілей сталого розвитку.

2. Надати характеристику основним аспектам циркулярної економіки.

3. Проаналізувати зв'язок між циркулярною моделлю економіки та змінами в логістичних системах.

Основний матеріал дослідження. Циркулярна економіка пропонує до застосування сучасні підходи та бізнес-моделі, які дозволяють підвищити ресурсо- та енергоефективність виробництва та споживання товарів, досягти зниження негативного впливу на навколишнє середовище.

Процеси екодеструктивного впливу людства на довкілля групуються за наступними напрямками:

- забруднення (хімічне, шумове, електромагнітне, теплове, радіаційне, біологічне та ін.);

- порушення ландшафтів (риття каналів, котлованів, оранка грунтів, формування відвалів, зміна русел річок, осушення боліт, затоплення територій та ін.);

- прямий вплив на організм людини (виробничий травматизм, професійні захворювання, підвищення радіаційного фону);

- вплив на характеристики людини як особистості (конвеєрне ви- робництво, інтенсифікація розумової діяльності та ін.);

- прямий негативний вплив на флору та фауну (загибель рослин та тварин від забруднення водойм, повітря, від транспорту тощо) [15].

Визначити ступінь екодеструктивного впливу на довкілля дозволяє спеціальний показник - екологічний слід, що відображає попит людської популяції на природний капітал, який може навіть перевищувати екологі чну спроможність планети до регенерації цього капіталу. Термін «екологічний слід» був введений в обіг у 1992 році канадським професором Вільямом Різом [35]. Це умовне поняття, що відображає споживання людством ресурсів біосфери та вимірюється площею (в га) продуктивної території, необхідної для ресурсного забезпечення життєдіяльності людства, а також для поглинання та переробки відходів.

Концепція розрахунку екологічного сліду швидко поширилася завдяки регулярним доповідям «Жива планета» («Living Planet Report») Всесвітнього фонду дикої природи (World Wildlife Fund, WWF), в останній 3 яких стверджується, що людський слід перевищив біопотенціал планети на $20 \%$ [36].

Екологічний слід в Україні становить 3,19 га на особу. Сьогодні кожна людина потребує в середньому 2,7 га, щоб забезпечити себе ресурсами і позбутися відходів, що значно більше спроможностей планети. Ідеальним у світі вважається екослід 1,8 га, який відображає реальні можливості планети. Таким чином, Україна опинилася на 51-у місці серед 149 країн за площею, яку використовує одна людина для споживання ресур- 
сів. Вплив середнього українця на довкілля перевищує порогове значення в 1,88 рази.

Відповідно до доповіді $\mathrm{OOH}$ «Перспективи зростання населення в світі» («World Population Prospects») [37] до 2030 року населення планети Земля зросте до 8,3 млрд. осіб, до середнього класу приєднається не менше 2,5 млрд. нових споживачів. Для задоволення їх потреб необхідно 3 урахуванням споживання первинних ресурсів, за оцінками експертів [38;
39], чотири таких планети, як Земля вже до 2050 року.

Зменшити наслідки екодеструктивного впливу на природу можливо завдяки впровадженню нових концепцій життєдіяльності. Простежується явний зв'язок між концепціями сталого розвитку, екологічної економіки та циркулярної економіки. Екологічна економіка $\epsilon$ одним зі способів досягнення сталого розвитку, а циркулярна економіка $€$ конкретним інструментом переходу до екологічної економіки (рис. 1).

Сталий розвиток - такий, що задовольняє потреби теперішнього часу, але не ставить під загрозу здатність майбутніх поколінь задовольняти свої власні потреби.

Екологічна (зелена) економіка забезпечує довгострокове підвищення добробуту людей без істотних ризиків екодеструктивного впливу на навколишнє середовище, тобто задовольняє умовам сталого розвитку.

Циркулярна (циклічна) економіка спрямована на підтримку цінності продуктів, матеріалів і ресурсів протягом якомога довшого часу шляхом їх повернення в виробничий цикл при мінімізації утворення відходів, тобто зменшує екодеструктивний вплив на довкілля.

Рис. 1. Зв'язок між концепціями сталого розвитку, екологічної та цииркулярної економіки

Джерело: розроблено автором

Циркулярна (циклічна) економіка (від англ. circular, cyclic есоnomy) є напрямком екологічної економіки, що дозволяє досягти цілей сталого розвитку. Перелік цілей сталого розвитку був затверджений на засіданнях Генеральної Асамблеї ООН у 2015 році. Цілі сталого розвитку, яких на сьогодні дотримуються всі країни світу, встановлюють показники розвитку і включають 17 ці- лей (SDGS) і 169 завдань, які мають бути досягнутими до 2030 року [36].

Застосування інструментарію циркулярної економіки дозволяє досягти деяких цілей сталого розвитку безпосередньо, а деяких - опосередковано. Наприклад, досягти SDGS 12 (забезпечення раціональних моделей споживання i виробництва) неможливо без впровадження бізнес-моделей циркулярної економіки. А до- 
DEVELOPMENT OF MANAGEMENT AND ENTREPRENEURSHIP METHODS ON TRANSPORT, № 3 (72), 2020 сягнення SDGS 12 вплине на досягнення інших SDGS сталого розвитку, в яких реалізуються принципи екологічної економіки, а саме: SDGS 6 (забезпечення наявності і раціонального використання водних ресурсів $\mathrm{i}$ санітарії для всіх), SDGS 7 (забезпечення доступу до недорогих, надійних, стійких і сучасних джерел енергії для всіх), SDGS 11 (забезпечення відкритості, безпеки, життєстійкості і стійкості міст і населених пунктів), SDGS 13 (прийняття термінових заходів по боротьбі зі зміною клімату i його наслідками), SDGS 14 (збереження та раціональне використання океанів, морів і морських ресурсів в інтересах сталого розвитку), SDGS 15 (захист, відновлення екосистем суші i сприяння їх ефективному використанню, раціональне управління лісами, боротьба 3 опустелюванням, припинення i повернення назад процесу деградації земель i припинення процесу втрати біологічного різноманіття). Методологічною основою циркулярної економіки $\epsilon$ парадигма індустріальної екології [40]. Основною ціллю індустріальної екології є заміна, наявної в більшості випадків, лінійної природи техногенної системи на циклічну систему, де відходи багаторазово використовуються у вигляді енергії або сировини для інших продуктів або процесів.

3 позицій індустріальної екології ідеальним станом техногенної системи вважається такий, при якому матеріально-енергетичні цикли ресурсів є замкнутими, організованими подібно природним екосистемам. Ця ідея замкнутості циклів обороту ресурсів, доповнена оцінками вартості природного капіталу [10], що відображають його значимість i корисність (а відповідно і потенційні втрати від вилучення ресурсів 3 відходами) [21], становить змістовну основу циркуляр-ної економіки [17].

Особливість циркулярної економіки визначається тим, що іiі peaлізація пов'язана 3 формуванням нових бізнес-моделей для забезпечення більш екологічного ресурсокористування [18; 19], що відображає операційний рівень функціонування економічної системи [21] та є регенеративною (відновлювальною) системою, яка зосереджується на повторному використанні ресурсів, компонентів, продуктів тощо.

Реалізація принципів циркулярної економіки здійснюється через п'ять загальновизнаних інноваційних бізнес-моделей, класифікованих спеціалістами компаніï Accenture [41] (табл.1). Не дивлячись на різноманітність циркулярних бізнес-моделей, їх використання направлено на: скорочення кількості ресурсів, матеріалів та енергії, що використовуються в процесі виробництва; використання екологічно чистих джерел ресурсів; зменшення кількості продуктів, що споживаються, завдяки переходу від індивідуального до спільного використання; продовження терміну корисного споживання продуктів; зменшення кількості відходів та раціональну їх утилізацію.

Циркулярна економіка $є$ альтернативою традиційному лінійному економічному механізму, оскільки для неї $\epsilon$ властивим замкнутий характер використання ресурсів та їх відновлювання. На відміну від традиційної моделі економіки, яка працює за принципом «добути, виробити, використати, викинути» («take, make, use, waste»), циркулярна економіка пропо- 
нує принципово нову стійку модель, яка базується на принципі «добути, виробити, використати, відновити або переробити, повторно використати» («take, make, use, repair or recycle, reuse»).

Таблиця 1

Бізнес-моделі цүиркулярної економіки

\begin{tabular}{|c|c|c|}
\hline $\begin{array}{c}\text { Назва } \\
\text { бізнес-моделі }\end{array}$ & $\begin{array}{l}\text { Характеристика } \\
\text { бізнес-моделі }\end{array}$ & $\begin{array}{l}\text { Компанії, що } \\
\text { проваджують } \\
\text { бізнес-модель }\end{array}$ \\
\hline $\begin{array}{l}\text { Циркулярні } \\
\text { поставки } \\
\text { (Circular suppliers) }\end{array}$ & $\begin{array}{l}\text { Забезпечує доставку постачальником ресурсів, } \\
\text { які повністю переробляються або біо- } \\
\text { розкладаються та лежать в основі циркулярної } \\
\text { системи виробництва і споживання. }\end{array}$ & $\begin{array}{l}\text { Ford, Fairphone, 3Д } \\
\text { Hubs, Desso, Toyota } \\
\text { Cisco }\end{array}$ \\
\hline $\begin{array}{l}\text { Відновлення } \\
\text { ресурсів } \\
\text { (Resources } \\
\text { recovery) }\end{array}$ & $\begin{array}{l}\text { Сприяє усуненню втрат ресурсів, зважаючи } \\
\text { на утворення відходів, і підвищує } \\
\text { рентабельність виробництва продукції від } \\
\text { зворотних потоків. }\end{array}$ & $\begin{array}{l}\text { Coca-Cola, Maersk, } \\
\text { Michelin, Philips, } \\
\text { Walt Disney World } \\
\text { Resort }\end{array}$ \\
\hline $\begin{array}{l}\text { Платформи для } \\
\text { обміну і спільного } \\
\text { використання } \\
\text { (Sharing platforms) }\end{array}$ & $\begin{array}{l}\text { Служить просуванню платформ для взаємо- } \\
\text { дії між користувачами продукту, окремими } \\
\text { особами або організаціями. }\end{array}$ & $\begin{array}{l}\text { Patagonia, Bla Bla- } \\
\text { car, Nearly New Car, } \\
\text { BMW, Drivy, } \\
\text { Daimler, Lyft }\end{array}$ \\
\hline $\begin{array}{l}\text { Продовження } \\
\text { життєвого циклу } \\
\text { продукції (Product } \\
\text { life extension) }\end{array}$ & $\begin{array}{l}\text { Забезпечує збереження або поліпшення } \\
\text { продукту, який був у використанні, за } \\
\text { рахунок його ремонту, модернізації, } \\
\text { реконструкції або відновлення. }\end{array}$ & $\begin{array}{l}\text { Bosch, Caterpillar, } \\
\text { Volvo, Renault, Ap- } \\
\text { ple, BMA Ergono- } \\
\text { mics, Michelin }\end{array}$ \\
\hline $\begin{array}{l}\text { Продукт як послуга } \\
\text { (Product as a service) }\end{array}$ & $\begin{array}{l}\text { Служить альтернативою купівлі продукту, } \\
\text { надаючи його в користування, наприклад, } \\
\text { через договір оренди, лізингу і т.П., що } \\
\text { підвищує стимули для створення довговічної } \\
\text { продукції, продовження ії життєвого циклу. }\end{array}$ & $\begin{array}{l}\text { Rolls-Royce, Mud } \\
\text { Jeans, De } \\
\text { Kledingbibliotheek }\end{array}$ \\
\hline
\end{tabular}

Джерело: [22]

Циркулярна модель $є$ вдалим способом заощадження ресурсів і матеріалів, зменшення негативного впливу на довкілля та стійкого економічного зростання.

У сучасних умовах перехід до циркулярної економіки можливий завдяки замиканню ресурсного циклу та створенню замкнутих ланцюгів поставок. Така можливість вперше з'явилась завдяки впровадженню рециклінгу - процесу повернення відходів в процес виробництва, який був одним $з$ перших процесів циркулярної економіки. В процесі розвитку концепції циркулярної економіки, сформувалися рамочні концептуальні структури - фреймворки, які по мірі посилення ідей циркулярності трансформувалися: «3R», «4R», «6R» та « R » $[19 ; 26]$. 
Характеристика процесів фреймворків циркулярної економіки

\begin{tabular}{|c|c|c|}
\hline $\begin{array}{c}\text { Рівень } \\
\text { циркулярності } \\
\text { економіки [26] }\end{array}$ & Фреймворк & Характеристика процесу \\
\hline \multirow[t]{2}{*}{$\begin{array}{l}\text { Перший рівень - } \\
\text { корисне викорис- } \\
\text { тання сировини та } \\
\text { матеріалів }\end{array}$} & $4 \mathrm{R}, 6 \mathrm{R}, 9 \mathrm{R}$ & $\begin{array}{l}\text { Recover (відновлення, повернення) - процес збору } \\
\text { продуктів і компонентів в кінці використання, розбирання, } \\
\text { сортування та очищення з метою використання в } \\
\text { наступних життєвих циклах [46]. }\end{array}$ \\
\hline & $\begin{array}{l}3 \mathrm{R}, 4 \mathrm{R}, \\
6 \mathrm{R}, 9 \mathrm{R}\end{array}$ & $\begin{array}{l}\text { Recycle (рециклінг, переробка) - процес повернення } \\
\text { відходів, скидів і викидів в процеси техногінезу [47]. } \\
\text { Повторне використання відходів за тим же призначенням, } \\
\text { а також повернення відходів після відповідної обробки в } \\
\text { виробничий цикл [2]. }\end{array}$ \\
\hline \multirow{5}{*}{$\begin{array}{l}\text { Другий рівень - } \\
\text { продовження термін } \\
\text { служби продукту і } \\
\text { його частин }\end{array}$} & $9 \mathrm{R}$ & $\begin{array}{l}\text { Refurbish (оновлення, ремонт) - відновлення та оновлення } \\
\text { старого але справного продукту [26]. }\end{array}$ \\
\hline & $6 \mathrm{R}, 9 \mathrm{R}$ & $\begin{array}{l}\text { Remanufacture (оновлення, модифікація) - процес } \\
\text { відновлення продукту для приведення його у робочий стан } \\
\text { шляхом заміни або ремонту основних вузлів або } \\
\text { компонентів [45]. }\end{array}$ \\
\hline & $9 \mathrm{R}$ & $\begin{array}{l}\text { Repurpose (переорієнтація) - перепрофілювання, } \\
\text { використання продукту, що вийшов зі строю, та його } \\
\text { частин в новому продукті з другим призначенням [48]. }\end{array}$ \\
\hline & 9R & $\begin{array}{l}\text { Repair (ремонт, виправлення) - ремонт та обслуговування } \\
\text { несправного продукта для використання відповідно до } \\
\text { оригінального призначення [49]. }\end{array}$ \\
\hline & $\begin{array}{l}3 \mathrm{R}, 4 \mathrm{R}, \\
6 \mathrm{R}, 9 \mathrm{R}\end{array}$ & $\begin{array}{l}\text { Reuse (повторне використання) передбачає, що якийсь } \\
\text { продукт використовується повторно для первісних або } \\
\text { нових цілей в первісному вигляді або з деякими змінами і } \\
\text { незначними поліпшеннями [44]. }\end{array}$ \\
\hline \multirow{4}{*}{$\begin{array}{l}\text { Третій рівень - } \\
\text { розумне вироб- } \\
\text { ництво та } \\
\text { використання } \\
\text { продукції }\end{array}$} & $\begin{array}{l}3 \mathrm{R}, 4 \mathrm{R}, \\
6 \mathrm{R}, 9 \mathrm{R}\end{array}$ & $\begin{array}{l}\text { Reduse (скорочення, зменшення) передбачає скорочення } \\
\text { використання ресурсів та енергії на етапах планування та } \\
\text { виробництва продукту, та скорочення викидів та відходів } \\
\text { на етапі його використання [49]. }\end{array}$ \\
\hline & 9R & $\begin{array}{l}\text { Rethink (переосмислення) - підвищення інтенсивності } \\
\text { використання продукту (наприклад, спільне використання) } \\
{[26] .}\end{array}$ \\
\hline & $9 \mathrm{R}$ & $\begin{array}{l}\text { Refuse (відмова) - скорочення надмірного споживання } \\
\text { продуктів за рахунок повної відмови від їх функціонала } \\
\text { шляхом передавання їх функціонала іншим продуктам } \\
\text { [26]. }\end{array}$ \\
\hline & $6 \mathrm{R}$ & $\begin{array}{l}\text { Redesign (перепроектування) - процес розробки продуктів } \\
\text { наступного покоління, в яких використовувалися б } \\
\text { компоненти, матеріали і ресурси, витягнуті з попереднього } \\
\text { життєвого циклу або продуктів попереднього покоління } \\
\text { (перепроектування з метою використання як можна більшої } \\
\text { кількості витягнутих компонентів і деталей без втрати } \\
\text { функціональності) [26]. }\end{array}$ \\
\hline
\end{tabular}

Джсерело: розроблено автором 
DEVELOPMENT OF MANAGEMENT AND ENTREPRENEURSHIP METHODS ON TRANSPORT, № 3 (72), 2020
РОЗВИТОК МЕТОДІВ

УПРАВЛІННЯ ТА ГОСПОДАРЮВАННЯ

НА ТРАНСПОРТІ, № 3 (72), 2020
Впровадження процесів фреймворків циркулярної економіки передбачає трансформацію бізнес-взаємодій, зокрема, шляхом імплементації суб'єктами господарської діяльності стратегій індустріального симбіозу та індустріального метаболізму [11; 51], коли взаємодія між елементами техногенної системи може здійснюватися на мікро-, мезо- та макрорівні в ресурсному забезпеченні за каскадним принципом, коли відходи одного виробництва $є$ сировиною для іншого, забезпечуючи тим самим зменшення екодеструктивного впливу на довкілля.

Фонд Еллен МакАртур трансформував принципи циркулярної економіки в модель, яка базується на процесах «6R» фреймворк та розглядає технічний й біологічний цикли (рис. 2) [2].

$\mathrm{y}$ межах біологічного циклу ця схема передбачає наступний ланцюг: нетоксичні відходи після використання потрапляють назад у природне середовище і стають живильним середовищем для біологічних організмів, а потім, в результаті подальших біологічних процесів, в якості біохімічної сировини та продуктів сільського господарства повертаються в процеси виробництва. Принципу функціонування біологічного циклу відповідає концепція «від колиски до колиски» («cradle-to-cradle»), в основу якої покладена ідея безвідходного виробництва [42].

Технічний цикл формує замкнуті ланцюги поставок та складається 3 наступних процесів:

- технічне обслуговування

(maintenance);
- повторне використання продукції (reuse/redistribute);

- відновлювальний ремонт продукції i/або відновлення компонентів, що відслужили (refurbish/remanufacture);

- рециклінг (recycle) (рис. 2).

Під технічним обслуговування (maintenance) розуміють ефективний спосіб збереження або відновлення продукції до бажаного рівня продуктивності 3 метою іiі захисту від подальшого пошкодження і продовження життєвого циклу, який включає в себе діагностику і ремонт [43].

Традиційна лінійна економіка представлена на рисунку 2 як вертикальний процес в середині, від видобутку ресурсів і виробництва до захоронення відходів.

Причому процес відновлення енергіï (energy recovery) в лінійній моделі присутній не завжди, часто процес збору відходів (collection) передує безпосередньо процесу захоронення відходів (landfill).

Також представлені два цикли циркулярної економіки - біологічних та технічних речовин. В лінійній моделі технічні матеріали не створюють послідовно замкнутий цикл споживання, що породжує втрати цінних матеріальних та енергетичних ресурсів.

По аналогії $з$ біологічними системами, які направлені на створення замкнутих циклів, в технічних системах впроваджується відновлення та відтворення продуктів, компонентів, матеріалів за допомогою повторного використання, ремонту, регенерації, рециркуляції тощо. 
DEVELOPMENT OF MANAGEMENT

AND ENTREPRENEURSHIP METHODS

ON TRANSPORT, № 3 (72), 2020
РОЗВИТОК МЕТОДІВ

УПРАВЛІННЯ ТА ГОСПОДАРЮВАННЯ

НА ТРАНСПОРТІ, № 3 (72), 2020

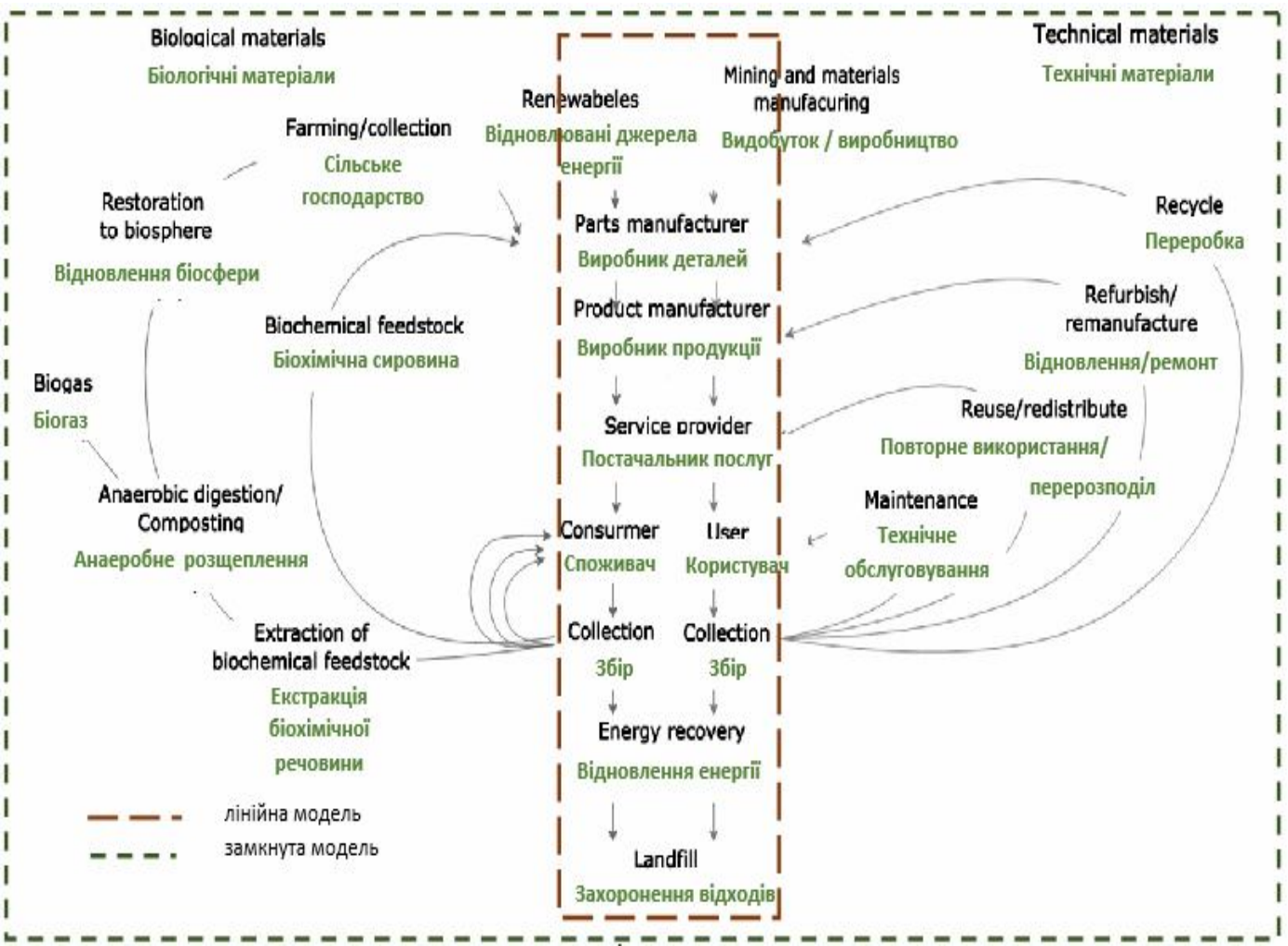

Рис. 2. Модель ииркулярної економіки, запропонована Фондом Еллен МакАртур

Джерело: удосконалено [2]

Лінійна економіка не є досконалою, оскільки постійно потребує залучення додаткових первинних ресурсів, які проходячи через техногенну систему, в результаті продукують велику кількість відходів. Циркулярна економіка враховує біологічний та технічний цикли обігу ресурсів та потенційні вигоди, які можуть бути отримані на різних рівнях цих циклів, вона передбачає перехід від лінійної економіки до економіки замкнутого циклу.

Реалізація замкнутої моделі циркулярної економіки можлива на мікро-, мезо- та макрорівнях. На мік- рорівні підприємство враховує екологічний фактор в процесах постачання сировини та матеріалів, виробництва та збуту продукції, поводження з відходами.

На мікрорівні втіленням ідеї циркулярної економіки $\epsilon$ замкнуті мікрологістичні системи. Крім того, на мікрорівні здійснюється екодизайн (ecodesign), що враховує екологічну складову постачання, виробництва та збуту, та є проявом еколого-орієнтованого управління. На мезорівні відбувається створення екопарків - об'єднань виробників товарів і послуг, які бажають поліпшити еко- 
номічний та екологічний стан шляхом спільного управління природними ресурсами і навколишнім середовищем. При цьому виробництво здійснюється в закритій системі, яка схожа на природні еко-системи, тобто відходи або побічні продукти одного виробничого ланцюга $\epsilon$ сировиною для іншого [24]. На макрорівні створюються еко-міста, еко-регіони тощо [50]. Отже, на мезо- та макрорівні ідеї циркулярної економіки втілюються через замкнуті ланцюги поставок та загальну екологізацію техногенних систем.

Циркулярна економіка створює замкнуті ланцюги поставок, які об'єднують звичайні процеси прямого ланцюга поставок зі зворотними логістичними процесами 3 першого до третього рівнів циркулярності економіки (від корисного використання сировини та матеріалів до розумного виробництва та відказу від надмірного споживання). Кінцева мета полягає в тому, щоб мінімізувати використання ресурсів та максимально зберегти цінність продуктів, що використовуються споживачами, завдяки впровадженню одного або кількох процесів фреймворків циркулярної економіки. Це дасть можливість зни- зити екодеструктивний вплив на навколишнє середовище та на протязі всього ланцюга поставок.

Висновки. Циркулярна економіка як складова екологічної економіки, яка дозволяє досягти цілей сталого розвитку, являє собою трансформаційний шлях, націлений на зміну світоглядної парадигми суспільства споживання на більш гуманну по відношенню до довкілля. Застосування циркулярних бізнес-моделей в різноманітних галузях економіки призводить до значних екологічних, соціальних та економічних переваг.

Циркулярна економіка $є$ альтернативою традиційному лінійному економічному механізму, оскільки для неї $\epsilon$ властивим замкнутий характер використання ресурсів та їх відновлювання. Еволюція принципів циркулярної економіки призвела до виникнення фреймворків, до складу яких входять процеси, які дозволяють перетворити лінійну модель економіки на замкнуту.

Умовою впровадження замкнутої моделі циркулярної економіки $\epsilon$ реорганізація логістичних бізнес-процесів, пов'язаних з управлінням матеріальними потоками, та створення замкнутих ланцюгів поставок.

\section{СПИСОК ЛІТЕРАТУРИ}

1. Тураев В.А. Глобальные вызовы человечеству: Учебное пособие. М.: Ло2oc, 2002. $192 \mathrm{c}$.

2. Ellen MacArthur Foundation: Towards a Circular Economy: Business Rationale For An Accelerated Transition. 2015. URL: https://www.ellenmacarthur foundation.org/assets/downloads/TCE_Ellen-MacArthur-Foundation9-Dec-2015.pdf (Дата обращения 20.04.2020)

3. Сочиально-экономический потенциал устойчивого развития: Учебник / Под. ред. проф. Л.Г. Мельника (Украина) и проф. Л. Хенса (Бельгия). Сумыл: ИТД «Университетская книга», 2007. 1120 c. 
4. Декларащия по окружающей среде и развитию. Рио-де-Жанейро. 3-14 июня 1992. URL: http://www.un.org/ru/documents/decl_conv/declarations/ riodecl.

5. Программа действий. Повестка дня на ХХІ век и другие документы Конференции в Рио-де-Жанейро в популярном изложении. Женева: Центр «За наме общее будущее», 1993. $70 \mathrm{c}$.

6. Програма ООН з навколишнього середовища (United Nations Environment Programme, ЮHЕП). URL: http://www.javirua.org/programa-organizaciïobyednanix-nacij-z-navkolishnogo-seredovishha-unep/

7. Медоуз Д., Рандерс Й., Медоуз Д. (2018). Межі зростання. 30 років потому. Киї: Пабулум. 464 c.

8. Closing the loop - An EU action plan for the Circular Economy. (2015). Communication from the commission to the european parliament, the council, the european economic and social committee and the committee of the regions, 2.12.2015, Brussels, COM (2015) 614 final. URL: http://eurlex.europa.eul legalcontent/EN/TXT/?qid=1453384154337\&uri=CELEX:52015DC0614.

9. Andersen, M.S. (2007). An introductory note on the environmental economics of the circular economy. Sustainability Science, 2(1), 133-140, DOI: https:// doi.org/10.1007/s11625-006-0013-6.

10. Costanza, R., de Groot, R., Sutton, P., van der Ploeg, S., Anderson, S.J., Kubiszewski, I., \& et al (2014). Changes in the global value of ecosystem services. Global Environmental Change, 26 (1), 152-158, DOI:https:// doi.org/ 10.1016/j.gloenvcha.2014.04.002.

11. Ayres, R. U. (2008). Sustainability economics: Where do we stand? Ecological Economics, 67(2), 281-310. DOI: https://doi.org/ 10.1016/j.ecolecon. 2007.12. 09

12. Chertow, M., \& Ehrenfeld, J. (2001). Industrial symbiosis: The legacy of Kalundborg. In: R. Ayres and L. Ayres (eds.) Handbook of Industrial Ecology (pp. 334-350). Cheltenham, UK: Edward Elgar.

13. Fischer-Kowalski, M., Krausmann, F., Giljum, S., Lutter, S., Mayer, A., Bringezu, S., ... \& et al (2011). Methodology and indicators of economy-wide material flow accounting: State of the art and reliability across sources. Journal of Industrial Ecology, 15 (6), 855-876, DOI: https://doi.org/ 10.1111/ j.1530-9290.2011.00366.x.

14. Коржнев М.М. Економіка природокористування. К.: Вид-во КНУ. 2005. $99 \mathrm{c.}$

15. Синякевич I.М. Економіка природокористування: Навч. посібник. К.: 3MH, 1996. $156 \mathrm{c}$.

16. Kalmykova, Y. \& Rosado, L. (2015). Urban Metabolism as Framework for Circular Economy Design for Cities. Proceedings of the World Resources Forum. Retrieved from http://publications.lib.chalmers.se/publication/232085urban-metabolism-as-framework-for-circular-economy-design-for-cities. 
17. Ghisellini, P., Cialani, C. \& Ulgiati, S. (2016). A review on circular economy: the expected transition to a balanced interplay of environmental and economic systems// Journal of Cleaner Production № 114, 11-32. DOI: https:// doi. org/10.1016/j.jclepro.2015.09.007.

18. Roos, G. Business model innovation to create and capture resource value in future circular material chains // Resources, 2014. № 3. P. 248-274. DOI: https://doi.org/10.3390/resources3010248.

19. Murray, A., Skene, K., Haynes, K. The Circular Economy: An Interdisciplinary Exploration of the Concept and Application in a Global Context // Journal of Business Ethics. 2015. DOI: 10.1007/s10551-015-2693-2.

20. Haas, W., Krausmann, F., Wiedenhofer, D., Heinz, M. How circular is the global economy?: An assessment of material flows, waste production, and recycling in the European union and the world in 2005 / W., Haas, F., Krausmann, D., Wiedenhofer, M., Heinz // Journal of Industrial Ecology. 2015. - № 19 (5). - P. 765-777. DOI: https://doi.org/10.1111/jiec.12244.

21. Мишенин Е.В., Коблянская И.И. Перспективы и механизмы развития «ииркулярной» экономики в глобальной среде // Маркетинг і менеджмент інновачій, № 2, 2017. C.329-343.

22. Пахомова Н.В., Рихтер К.К., Ветрова М.А. Переход к ииркулярной экономике и замкнутым цепям поставок как фактор устойчивого развития // Вестник СПбГУ. Экономика. 2017. T. 33. Bып. 2 C. 244-268.

23. Батова Н., Сачек П., Точицкая И. На пути к зеленому росту: окно возможностей ииркулярной экономики // BEROC Green Economy Policy Paper Series. 2018. URL: http://www.beroc.by/greeneconomy/research/ge-2/ (дата обращения 05.03.2019).

24. Батова Н., Сачек П., Точиикая И. Циркулярная экономика в действии: формы организачии и лучшие практики // BEROC Green Economy Policy Paper Series. 2018. URL: http://www.beroc.by/greeneconomy/research/ge-5/ (дата обращения 05.03.2019).

25. Валько, Д.В. Циркулярная экономика: теоретическая модель и эффекты реализации // Наџиональные интересы: приоритеть и безопасность, 2018, T. 14, Butn. 8, C.1415-1429.

26. Валько Д.В. Циркулярная экономика: понятийный аппарат и диффузия кониепиии в отечественных исследованиях // Научный журнал НИУ ИТМО. Серия Экономика и экологический менеджмент № 2, 2019. C.42-49.

27. Geng, Y.; Zhu, Q.; Doberstein, B.; Fujita, T. (2009). Implementing China's circular economy concept at the regional level: A review of progress in Dalian, China. Waste Management. 29, 996-1002.

28. Yuan, Z., Bi, J., Moriguichi, Y. (2006). The circular economy: A new development strategy in China. Journal of Industrial Ecology.10, 4-8.

29. Zink, T.; Geyer, R. (2017) Circular economy rebound. Journal of Industrial Ecology, 21: 593-602. 
30. Geissdoerfer, M. The Circular Economy - a new sustainability paradigm?// Journal of Cleaner Production (accepted version). URL: http://dx.doi.org/ 10.1016/j.jclepro.2016.12.0488.

31. Bastein, T. et al. (2013), Opportunities for a Circular Economy in the Netherlands, TNO, Report commissioned by the Netherlands Ministry of Infrastructure and Environment.

32. Hislop, H. \& Hill, J. (2011). Reinventing the wheel: A circular economy for resource security. London: Green Alliance.

33. Ingebrightsen, S., \& Jakobsen, O. (2007) Circulation Economics. Peter Lang.

34. Ellen MacArthur et al. (2016) Intelligent Assets: Unlocking the circular economy potential. Foundation Ellen MacArthur Foundation. URL: https://www.ellenmacarthurfoundation.org/assets/down-loads/publications/ EllenMacArthurFoundation_Intelligent_Assets_080216-AUDIO-E.pdf.

35. Освіта в інтересах сталого розвитку в Україні. URL: http://ecoosvita.org. ua/ calc

36. Цели в области устойчивого развития // Организаџия Объединенных Hаций [Oфициальный сайт]. URL: http://www.un.org/sustainable development/ru/summit

37. United Nations, Department of Economic and Social Affairs, Population Division (2015). World Population Prospects: The 2015 Revision, Key Findings and Advance Tables. Working Paper No. ESA/P/WP.241. URL: https:// esa.un.org/unpd/wpp/publications/files/key_findings_wpp_2015.pdf

38. Vaughn, J. The circular economy// J. Walter Thompson Company, 2014. URL: www.jwtintelligence.com/2014/06/trend-report-the-circular-economy/

39. Brinkman, J. Waste to Wealth / Accenture. URL: ec.europa.eu/environment/integration/green_semester/pdf/07_09_2015/5.\%20Accenture\%20-\%20 Waste\%20to\%20wealth\%20-\%20creating\%20advantage-final.pdf

40. Moriguchi, Y. Material flow indicators to measure progress toward a sound material-cycle society // Journal of Material Cycles and Waste Management. 2007. № 9(2). P. 112-120. DOI: https://doi.org/10.1007/s10163-007-0182-0.

41. Accenture. Circular Advantage: Innovative Business Models and Technologies to Create Value in a World without Limits to Growth / Accenture. 2014. URL: Braungart, M., McDonough $W$. Cradle to cradle: Remaking the way we make things. North Point Press, 2010. 208 p.

42. Ajukumar, V., Gandhi, O. Evaluation of green maintenance initiatives in design and development of mechanical systems using an integrated approach // Journal of Cleaner Production. 2013. Vol. 51. P. 34-46.

43. Amelia, L. et al. Initiating automotive component reuse in Malaysia // Journal of Cleaner Production. 2009. Vol. 17, issue 17. P. 1572-1579.

44. Gray, C., Charter, M. Remanufacturing and product design // International Journal of Product Development. 2008. Vol. 6, N 3/4. P. 375-392.

45. Houshyar, A., Hoshyar, A., Sulaiman, R. Review Paper on Sustainability in Manufacturing System // Journal of Applied Environmental and Biological Sciences. 2014. vol. 4(4). pp. 7-11. 
46. Межгосударственный стандарт ГОСТ 30772-2001 «Ресурсосбережение. Обрамение с отходами. Термины и определения» [Resources saving. Waste treatment. Terms and definitions] / Vveden v deistvie postanovleniem Gosstandarta RF ot 28 dekabrya 2001 g. № 607-st. URL: docs.cntd.rul document/gost-30772-2001 (data obrashcheniya 20.05.2020).

47. Potting, J., Hekkert, M., Worrell, E., Hanemaaijeret, A. Circular Economy: Measuring Innovation in the Product Chain / Netherlands Environmental Assessment Agency, 2017. 46 p. URL: www.pbl.nl/sites/default/files/cms / publicaties/pbl-2016-circular-economy-measuring-innovation-in-productchains-2544.pdf (дата обращения 20.05.2020).

48. Van Buren, N. et al. Towards a circular economy: the role of dutch logistics industries and governments // Sustainability. 2016.\#647. URL: www.mdpi.com/ 2071-1050/8/7/647 (дата обращения 12.04.2020).

49. Ghisellini, P., Cialani, C. and Ulgiati, S. (2014). Review on circular economy: the expected transition to a balanced interplay of environmental and economic systems. Journal of Cleaner Production. 114, 11-32.

50. Ravetz, J. (2003). Regional industrial ecology and resource productivity - new approaches to analysis and communication. Paper to ASEAT Conference \& Workshop «industrial Ecology \& Spaces of Innovation», (April, 2003). URL: https://www.academia.edu/4186753/Regional_industrial ecology_and_resource_productivity_new_approaches_to_analysis_and_comunication.

\section{REFERENCES}

1. Turaev, V., A. (2002). Global nie vizovi chelovechestvu [Global challenges to humanity]. Uchebnoe posobie. M.: Logos, 192 [in Russian].

2. Ellen MacArthur (2015). Foundation: Towards a Circular Economy: Business Ratio. Retrieved from https://www.ellenmacarthurfoundation.org/assets/ downloads/TCE_Ellen-MacArthur-Foundation-9-Dec-2015.pdf (Data obrashcheniya 20.04.2020).

3. Socy'al 'no-ekonomy'chesky`j potency'al ustojchy'vogo razvy'ty'ya [Socioeconomic potential of sustainable development] (2007). Uchebnik / Pod. red. prof. L.G., Mel'nika \& prof. L., Hensa (Bel'giya). Sumy: ITD «Universitetskaya kniga», 1120 [in Ukraine].

4. Deklaracy ya po okruzhayushhej srede $y^{\prime}$ razvy'ty'yu [Deklaraciya po okruzhayushchej srede i razvitiyu] (1992). Rio-de-ZHanejro. 3-14 iyunya. Retrieved from http://www.un.org/ru/documents/decl_conv/declarations / riodecl [in Russian].

5. Programma dejstvij. Povestka dnya na 21 vek $i$ drugie dokumenty Konferencii $v$ Rio-de-Zhanejro v populyarnom izlozheniim [Program of action. Agenda 21 and other documents of the Rio de Janeiro Conference in popular form] (1993). ZHeneva: Centr "Za nashe obshchee budushchee», 70 [in Russian].

6. Programa OON z navkolishn'ogo seredovishcha (United Nations Environment Programme, YUNEP). Retrieved from http://www.javirua.org/ programaorganizaciï-obyednanix-nacij-z-navkolishnogo-seredovishha-unep/ [in USA]. 
7. Meadows, Donella, Randers, Jorgen, \& Meadows, Dennis. (2018). Mezhi zrostannya. 30 rokiv potomu [Limits of growth. 30 years later]. Kyiv: Pabulum, 464 p. [in Ukraine].

8. Closing the loop - An EU action plan for the Circular Economy (2015). Communication from the commission to the european parliament, the council, the european economic and social committee and the committee of the regions, 2.12.2015, Brussels, COM, 614 final. Retrieved from http://eurlex. europa. eu/legalcontent/EN/TXT/?qid=1453384154337\&uri $=$ CELEX:52015DC0614.

9. Andersen, M.S. (2007). An introductory note on the environmental economics of the circular economy. Sustainability Science, 2(1), 133-140, DOI: https:// doi.org/10.1007/s11625-006-0013-6.

10. Costanza, R., de Groot, R., Sutton, P., van der Ploeg, S., Anderson, S.J., Kubiszewski, I., \& et al (2014). Changes in the global value of ecosystem services. Global Environmental Change, 26 (1), 152-158, DOI: https://doi.org/ 10.1016/j.gloenvcha.2014.04.002.

11. Ayres, R.U. (2008). Sustainability economics: Where do we stand? Ecological Economics, 67 (2), 281-310. DOI: https://doi. org/10.1016/j.ecolecon. 2007. 12.009 .

12. Chertow, M., \& Ehrenfeld, J. (2001). Industrial symbiosis: The legacy of Kalundborg. In: R. Ayres and L. Ayres (eds.) Handbook of Industrial Ecology (pp. 334-350). Cheltenham, UK: Edward Elgar.

13. Fischer-Kowalski, M., Krausmann, F., Giljum, S., Lutter, S., Mayer, A., Bringezu, S., ... \& et al (2011). Methodology and indicators of economy-wide material flow accounting: State of the art and reliability across sources// Journal of Industrial Ecology, 15 (6), 855-876. DOI: https://doi.org/ 10.1111/j. 1530-9290.2011.00366.x.

14. Korzhnev, M.M. (2005). Ekonomika prirodokoristuvannya [Environmental economics]. K.: Vid. KNU, 99 [in Ukraine].

15. Sinyakevich, I.M. (1996). Ekonomika pry rodokory stuvannya [Environmental economics]. Navch. posibnik. K.: IZMN, 156 [in Ukraine].

16. Kalmykova, Y. \& Rosado, L. (2015). Urban Metabolism as Framework for Circular Economy Design for Cities. Proceedings of the World Resources Forum. Retrieved from http://publications.lib.chalmers.se/publication/232085urban-metabolism-as-framework-for-circular-economy-design-for-cities.

17. Ghisellini, P., Cialani, C. \& Ulgiati, S. (2016). A review on circular economy: the expected transition to a balanced interplay of environmental and economic systems// Journal of Cleaner Production № 114, 11-32. DOI: https:// doi. org/10.1016/j.jclepro.2015.09.007.

18. Roos, G. (2014). Business model innovation to create and capture resource value in future circular material chains. № 3, 274. DOI: https://doi.org /10. 3390/resources3010248.

19. Murray, A., Skene K. \& Haynes, K. The Circular Economy (2015): An Interdisciplinary Exploration of the Concept and Application in a Global Context. Journal of Business Ethics. DOI: doi:10.1007/s10551-015-2693-2 
20. Haas, W., Krausmann, F., Wiedenhofer, D. \& Heinz, M. (2015). How circular is the global economy?: An assessment of material flows, waste production, and recycling in the European union and the world in 2005// Journal of Industrial Ecology. № 19 (5), 765-777. DOI: https://doi.org/ 10.1111 /jiec. 12244.

21. Mishenin, E.V. \& Koblyanskaya, I.I. (2017). Perspekty vi y' mexany zmi razvy'ty'ya "cy'rkulyarnoj» ekonomy 'ky' $v$ global noj srede [Prospects and mechanisms for the development of the "circular» economy in the global environment]. Marketing and management innovation. № 2, 329-343 [in Ukraine].

22. Pahomova, N.V., Rihter, K.K. \& Vetrova, M.A.(2017). Perexod k cy 'rkulyarnoj ekonomy'ke $y^{\prime}$ zamknutim cepyam postavok kak faktor ustojchy'vogo razvy ty ya [Transition to a circular economy and closed supply chains as a factor in sustainable development]. Vestny`k SPbGU. Ekonomika - Vestnik SPbGU. Ekonomics. T.33. Vyp.2, 244-268 [in Russian].

23. Batova, N., Sachek, P. \& Tochickaya, I. (2018). Na puty $k$ zelenomu rostu: okno vozmozhnostej cy'rkulyarnoj ekonomy 'ky' [Towards green growth: a window of opportunity for a circular economy]. BEROC Green Economy Policy Paper Series. Retrieved from http://www.beroc.by/greeneconomy/ research/ge-2/ (data obrashcheniya 05.03.2019) [in Russian].

24. Batova, N., Sachek, P. \& Tochickaya, I. (2018). Cy'rkulyarnaya ekonomy ka v dejstvy 'y' formi organy zacy 'y ' $y^{\prime}$ luchshy'e prakty 'ky' [Circular economics in action: forms of organization and best practices]. BEROC Green Economy Policy Paper Series. Retrieved from http //www.beroc.by/ greeneconomy/research/ge-5/ (data obrashcheniya 05.03.2019) [in Russian].

25. Val'ko, D.V. (2018). Cy 'rkulyarnaya эkonomy 'ka: teorety 'cheskaya model'y' Iffektbl realyzacy' 'Circular economics: theoretical model and implementation effects]. Nacional'nye interesy: prioritety i bezopasnost' - National interests: priorities and security. T. 14, Vyp. 8, 1415-1429 [in Russian].

26. Val'ko, D.V. (2019). Cirkulyarnaya ekonomika: ponyatijnyj apparat i diffuziya koncepcii $v$ otechestvennyh issledovaniyah Nauchnyj zhurnal NIU ITMO. Seriya Ekonomika i ekologicheskij menedzhment № 2, 42-49 [in Russian].

27. Geng, Y.; Zhu, Q.; Doberstein, B. \& Fujita, T. (2009) Implementing China's circular economy concept at the regional level: A review of progress in Dalian, China. Waste Management. 29, 996-1002.

28. Yuan, Z., Bi, J. \& Moriguichi, Y. (2006). The circular economy: A new development strategy in China// Journal of Industrial Ecology. 10, 4-8.

29. Zink, T. \& Geyer, R. (2017). Circular economy rebound// Journal of Industrial Ecology, 21: 593-602.

30. Geissdoerfer, M. The Circular Economy - a new sustainability paradigm?// Journal of Cleaner Production (accepted version). Retrieved from http://dx.doi.org/10.1016/j.jclepro.2016.12.0488.

31. Bastein, T. et al. (2013). "Opportunities for a Circular Economy in the Netherlands», TNO, Report commissioned by the Netherlands Ministry of Infrastructure and Environment. 
32. Hislop, H. \& Hill, J. (2011). Reinventing the wheel: A circular economy for resource security. London: Green Alliance.

33. Ingebrightsen, S., \& Jakobsen, O. (2007). Circulation Economics. Peter Lang.

34. Ellen MacArthur et al. (2016). Intelligent Assets: Unlocking the circular economy potential. Foundation Ellen MacArthur Foundation. Retrieved from https://www.ellenmacarthurfoundation.org/assets/down-loads/ publications/ EllenMacArthurFoundation_Intelligent_Assets_080216-AUDIO-E.pdf

35. Osvita $v$ interesax stalogo rozvy'tku $\bar{v}$ Ukrayini [Education for sustainable development in Ukraine]. Retrieved from http://ecoosvita.org.Ua /calc. [in Ukraine].

36. Cely`v oblasty` ustojchy 'vogo razvy'ty ya [Sustainable development goals]. Oficial'nyj sajt Organizaciya Ob"edinennyh Nacij - United Nations Official site. Retrieved from http://www.un.org/sustainabledevelopment/ru/summit

37. United Nations, Department of Economic and Social Affairs, Population Division (2015). World Population Prospects: The 2015 Revision, Key Findings and Advance Tables. Working Paper No. ESA/P/WP.241. Retrieved from https://esa.un.org/unpd/wpp/publications/files/key_findings_wpp_ 2015.pdf.

38. Vaughn, J. (2014). The circular economy / J. Walter Thompson Company. Retrieved from www.jwtintelligence.com/2014/06/trend-report-the-circulareconomy

39. Brinkman, J. (2015). Waste to Wealth. Accenture. Retrieved from ec.europa. eu/environment/integration/green semester/pdf/07 09 2015/5.\% 20 Accenture\%20-\%20Waste\%20to\%20wealth\%20-\%20creating\% 20advantage-final.pdf.

40. Moriguchi Y. (2007). Material flow indicators to measure progress toward a sound materialcycle society. Journal of Material Cycles and Waste Management. № 9(2), P. 112-120. DOI: https://doi.org/10.1007/s10163-007-0182-0.

41. Accenture. Circular Advantage: Innovative Business Models and Technologies to Create Value in a World without Limits to Growth / Accenture. 2014. Retrieved from https://www.accen-ture.com /t20150523T053139 w /usen/ acnmedia/Accenture/ConversionAssets/DotCom/Documents/ Giobal/ PDF/ Strategy_6/Accenture-Circular-Advantage-Innovative-Business-Models-Technologies-Value-Growth.pdf

42. Ajukumar, V. \& Gandhi, O. (2013). Evaluation of green maintenance initiatives in design and development of mechanical systems using an integrated approach // Journal of Cleaner Production. Vol. 51, 34-46.

43. Amelia, L. \& et al. (2009). Initiating automotive component reuse in Malaysia // Journal of Cleaner Production. Vol. 17, issue 17, 1572-1579 [in English].

44. Gray, C. \& Charter, M. (2008). Remanufacturing and product design // International Journal of Product Development. Vol. 6, N 3/4 375-392.

45. Houshyar, A., Hoshyar, A. \& Sulaiman, R. (2014). Review Paper on Sustainability in Manufacturing System // Journal of Applied Environmental and Biological Sciences.vol. 4(4), 7-11. 
46. Mezhgosudarstvennyi standart GOST 30772-2001. "Resursosberezhenie. Obrashchenie s otkhodami. Terminy i opredeleniya» [Interstate standard GOST 30772-2001 "Resource saving. Waste management. Terms and Definitions»] (2001). [Resources saving. Waste treatment. Terms and definitions. Resource saving. Waste management. Terms and Definitions]. Vveden $v$ deistvie postanovleniem Gosstandarta RF ot 28 dekabrya $2001 \mathrm{~g}$. № 607-st. Retrieved from docs.cntd.ru/document/gost-30772-2001 (data obrashcheniya 20.05.2020) [in Russian].

47. Potting, J., Hekkert, M., Worrell, E. \& Hanemaaijeret, A. (2017). Circular Economy: Measuring Innovation in the Product Chain. Netherlands Environmental Assessment Agency, 2017. 46 p. Retrieved from www.pbl.nl/ sites/ default/files/cms /publicaties/pbl-2016-circular-economy-measuring-innovation-in-product-chains-2544.pdf (data obrashcheniya 20.05.2020).

48. Van Buren, N. \& et al. (2016). Towards a circular economy: the role of dutch logistics industries and governments. Sustainability. \#647. Retrieved from www.mdpi.com/2071-1050/8/7/647 (data obrashcheniya 12.04.2020).

49. Ghisellini, P., Cialani C. \& Ulgiati S. (2014). Review on circular economy: the expected transition to a balanced interplay of environmental and economic systems. Journal of Cleaner Production. 114, 11-32.

50. Ravetz, J. (2003). Regional industrial ecology and resource productivity - new approaches to analysis and communication. Paper to ASEAT Conference \& Workshop «industrial Ecology \& Spaces of Innovation». Retrieved from https:// www.academia.edu/4186753/Regional_industrial_ecology_and_resource_ productivity_new_approachesto_analysis_and_communication.

Стаття надійшла до редакиії 25.05.2020

Посилання на статтю: Ковтун Т.А. Впровадження принципів циркулярної економіки для досягнення цілей сталого розвитку // Розвиток методів управління та господарювання на транспорті: Зб. наук. праць, 2020. № 3 (72). С. 22-42. DOI 10.31375/2226-1915-2020-3-22-42.

Article received 25.05.2020

Reference a JournalArtic: Kovtun, Tetiana (2020). Implementation of the circular economy principles to achieve sustainable development goals. 3 (72), 22-42. DOI 10.31375/2226-1915-2020-3-22-42. 